\title{
Comparative analysis of sialidase protein in velogenic and lentogenic strains of Newcastle disease virus
}

\author{
M. ESMAELIZAD, M.P. ASHTIANI
}

Biotechnology Department, Central Laboratory, Razi Vaccine and Serum Research Institute, Karaj, Alborz, Iran

Received October 21, 2014; accepted May 15, 2015

\begin{abstract}
Summary. - The sialidase protein is a major part of hemagglutinin-neuraminidase (HN) protein of Newcastle disease virus (NDV), which is an important multifunctional envelope protein. This protein plays key roles in virus attachment to cells and virus-cell fusion. In this study, we compared the sialidase protein of Iranian virulent velogenic field strains with that of avirulent lentogenic strains. Six of seventeen variations in amino acid 395, 523, 550432,479 and 540 were observed near the catalytic and glycosylation sites in the sialidase protein. The obtained results showed fundamental differences in various biological parameters such as post-translational modification, antigenic index and electrostatic potential of tertiary structure of the sialidase protein. We suggest these six amino acids might play an effective role in the pathogenesis of NDV.
\end{abstract}

Keywords: Newcastle disease virus; sialidase; pathogenesis

\section{Introduction}

Newcastle disease is a highly contagious and lethal viral disease of birds. It is caused by the Newcastle disease virus (NDV), which has been categorized into three main pathotypes depending on the severity of the disease in chickens: the lentogenic, mesogenic and velogenic strains. Lentogenic strains are avirulent and may cause mild respiratory infection. Mesogenic strains are of intermediate virulence. Velogenic strains are highly virulent and cause high mortality. Velogenic strains cause hemorrhagic lesions in the digestive tract (Alexander, 1997). NDV is a member of the family Paramyxoviridae, in the order Mononegavirales (McGinnes et al., 1995; Lamb et al., 1996; Krishnamurthy et al., 1998). The velogenic strains of NDV have also been identified as potential animal pathogens, resulting in vast impacts on agricultural economy. Thus, it is important to understand the role of antigens for pathogenesis of Newcastle disease

E-mail: m.Esmaelizad@rvsri.Ac.Ir; phone: +(98)2634570038-2266. Abbreviations: $\mathrm{hn}=$ hemagglutinin-neuraminidase; $\mathrm{ndv}(\mathrm{s})=$ newcastle disease virus(es); $\mathrm{spf}=$ specific pathogen virus on the amino acids level and to explore technologies for designing alternative safe and efficient vaccines.

The HN protein plays an important role in the attachment of the virus to cells and cleaves sialic acid receptor from viral and cellular surfaces. HN also promotes cell fusion by interacting with the F protein of NDV. Thus, the $\mathrm{HN}$ has both hemagglutinating and neuraminidase activity (Lamb et al., 1996). The HN protein is a type II glycoprotein containing six glycosylation sites. Glycosylation of proteins helps in protein folding, biological activities and influences antigenicity and immunogenicity (McGinnes, 1995). In this study, we attempted to compare the sialidase protein between the velogenic isolates from Iran and known lentogenic NDV strains and investigated the amino acid differences that might be involved in pathogenesis.

\section{Materials and Methods}

Virus samples. In this study, the 27 virulent NDV samples were isolated from Newcastle disease outbreaks in seven provinces of Iran (Tehran, Khorasan, Kerman Azerbaijan, Qazvin, Qom and 


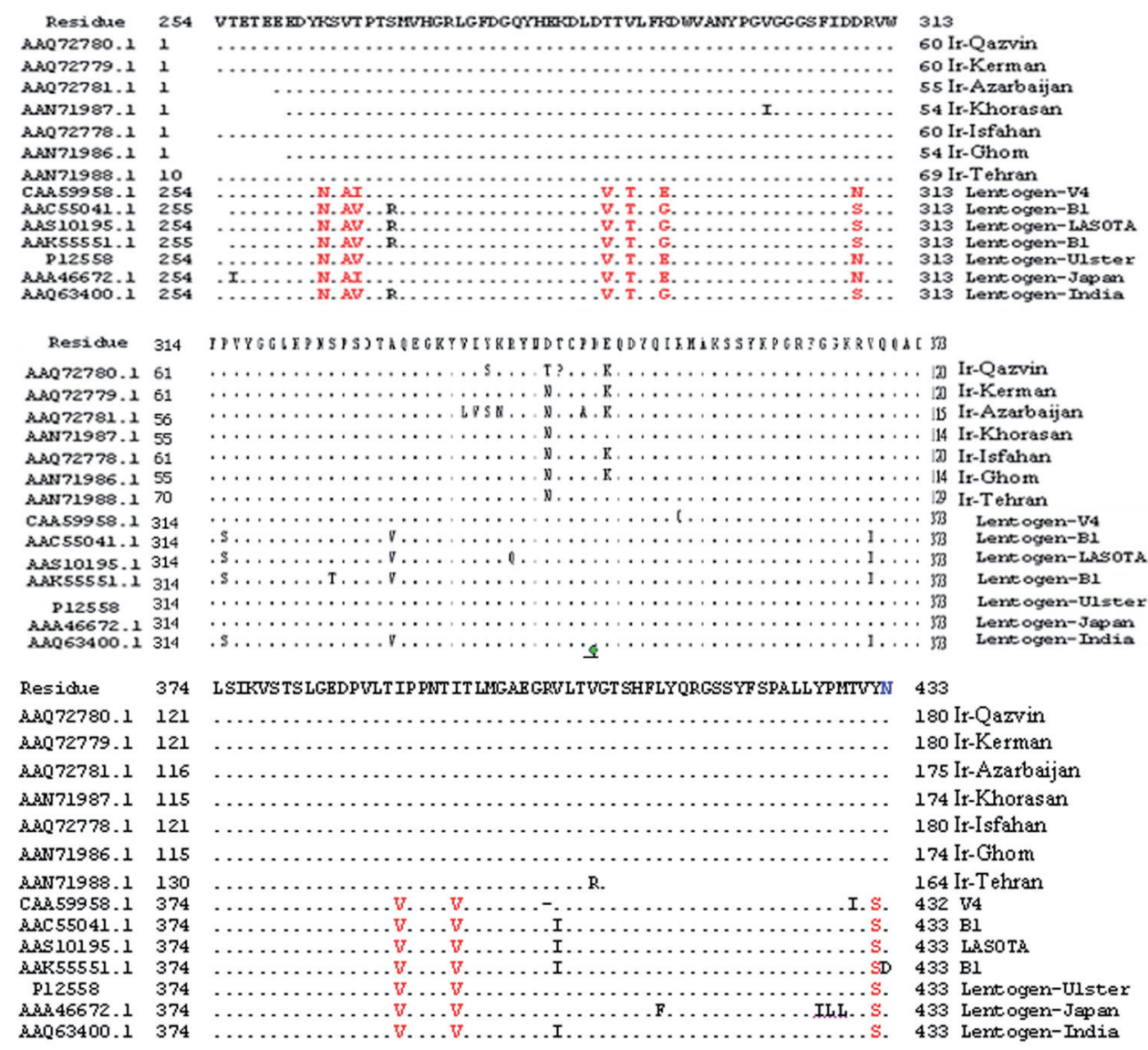

\begin{tabular}{|c|c|c|c|}
\hline Resicue & 434 & KT ATLHS PYTFNAF TRP GSUPCOASARCPNPCIT GUYTD PYP LWHRNHTLRGWFGTHLD & 493 \\
\hline $\mathrm{AMQ} 072780.1$ & 181 & $\cdots$ & 240 Ir-Qazvin \\
\hline A 3072779.1 & 181 & n.............. & 240 Ir-Kerman \\
\hline 83072781.1 & 176 & 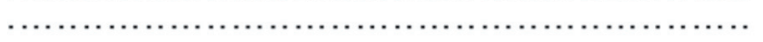 & 235 Ir-Azarbaijan \\
\hline A.N71987.1 & 175 & $\ldots \ldots \ldots \ldots$ & 234 Ir-Khorasan \\
\hline 8.072778 .1 & 181 & ... & 240 Ir-Isfahan \\
\hline $\begin{array}{l}\text { SAN71986.1 } \\
\text { CAS59958.1 } \\
\text { AAC55041.1 }\end{array}$ & $\begin{array}{l}175 \\
433 \\
434\end{array}$ & 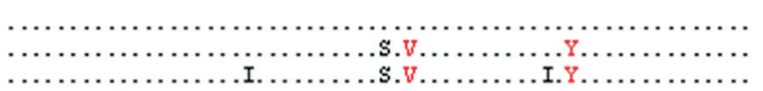 & $\begin{array}{l}234 \mathrm{Ir}-\text { Ghom } \\
492 \mathrm{~V} 4 \\
493 \mathrm{Bl}\end{array}$ \\
\hline A.3S10195.1 & 434 & 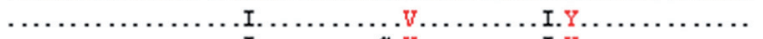 & 493 LASOTA \\
\hline A.3K55551.1 & 434 & n............... & $493 \mathrm{Bl}$ \\
\hline $\mathrm{P} 12558$ & 434 & n........................... & 493 Lentogen-Ulster \\
\hline $\operatorname{sis} 46672.1$ & 434 & 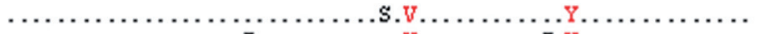 & 493 Lentogen-Jasam \\
\hline $\mathrm{A} .063400 .1$ & 434 & 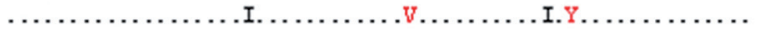 & 493 Lentogen-India \\
\hline Resiche & 494 & 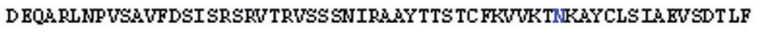 & 553 \\
\hline ג.3.072780.1 & 241 & 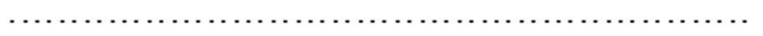 & $300 \mathrm{It}-\mathrm{Q} a z v i n$ \\
\hline 20.072779 .1 & 241 & 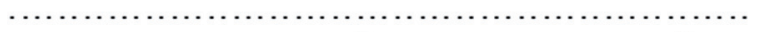 & 300 Ir-Kerman \\
\hline 23072781.1 & 236 & n.m.m. & 295 It-Azarbaijan \\
\hline A.AN71987.1 & 235 & $\ldots \ldots \ldots \ldots \ldots \ldots \ldots$. ST. . . LSR & 277 Ir-Khorasan \\
\hline ג.3.072778.1 & 241 & $\ldots \ldots \ldots \ldots$ & 254 It-Isfahan \\
\hline A.SN71986.1 & $\begin{array}{l}235 \\
493\end{array}$ & & 248 Ir-Ghom \\
\hline A.AC55041.1 & $\begin{array}{l}493 \\
494\end{array}$ & 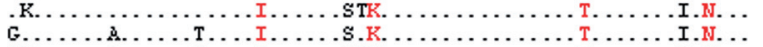 & $552 \mathrm{~V} 4$ \\
\hline 195.1 & 494 & А. & 553 LASOTA \\
\hline A_SK55551.1 & 494 & I.N. . & $553 \mathrm{Bl}$ \\
\hline $\begin{array}{l}\text { P } 12558 \\
0.2 .46672 .1\end{array}$ & $\begin{array}{l}494 \\
494\end{array}$ & 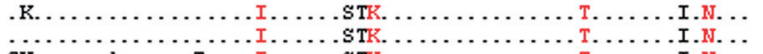 & $\begin{array}{l}553 \text { Lentogen-Ulster } \\
553 \text { Lentogen-Japan }\end{array}$ \\
\hline 0.963400 .1 & 494 & GV.......... & 553 Lentogen-India \\
\hline
\end{tabular}

Fig. 1

Sialidase protein sequences of lentogenic and velogenic strains of NDVs 
Table 1. Amino acid variations in the sialidase protein between virulent and avirulent NDV

\begin{tabular}{|c|c|c|c|c|c|}
\hline Velogenic & Lentogenic & Residue & Velogenic & Lentogenic & Residue \\
\hline I(Ile) & $\mathrm{V}(\mathrm{Val})$ & 395 & K(Lys) & $\mathrm{N}($ Asn $)$ & 263 \\
\hline $\mathrm{Y}(\mathrm{Tyr})$ & S(Ser) & 432 & $\mathrm{~V}(\mathrm{Val})$ & A(Ala) & 265 \\
\hline I(Ile) & $\mathrm{V}(\mathrm{Val})$ & 466 & $\mathrm{~T}(\mathrm{Thr})$ & $\begin{array}{c}\text { I(Ile) } \\
\text { /V(Val) }\end{array}$ & 266 \\
\hline $\mathrm{H}$ (His) & $\mathrm{Y}(\mathrm{Tyr})$ & 479 & $\mathrm{~T}(\mathrm{Thr})$ & $\mathrm{V}(\mathrm{Val})$ & 288 \\
\hline $\mathrm{V}(\mathrm{Val})$ & $\mathrm{I}(\mathrm{Ile})$ & 514 & $\mathrm{~V}(\mathrm{Val})$ & $\mathrm{T}(\mathrm{Thr})$ & 290 \\
\hline $\mathrm{R}($ Arg) & K(Lys) & 523 & K(Lys) & $\begin{array}{l}\text { E(Glu) } \\
\text { /G(Gly) }\end{array}$ & 293 \\
\hline $\mathrm{A}(\mathrm{Ala})$ & $\mathrm{T}(\mathrm{Thr})$ & 540 & $\mathrm{D}($ Asp) & $\begin{array}{l}\mathrm{N}(\text { Asn }) \\
\text { /S(Ser) }\end{array}$ & 310 \\
\hline \multirow[t]{2}{*}{$\mathrm{D}(\mathrm{Asp})$} & $\mathrm{N}($ Asn $)$ & 550 & $\begin{array}{c}\mathrm{N}(\text { Asn }) / \\
\mathrm{T}(\text { Thr })\end{array}$ & $\mathrm{D}(\mathrm{Asp})$ & 342 \\
\hline & & & I(Ile) & $\mathrm{V}(\mathrm{Val})$ & 390 \\
\hline
\end{tabular}

Isfahan). The samples were grown in SPF embryonated chicken eggs (McGinnes and Morrison, 1995).

RNA extraction. Total RNA was extracted from infected allantoic fluid using an RNX reagent (Cinnagen, Iran). Briefly, allantoic fluid ( $1 \mathrm{ml}$ ) was centrifuged at $35,000 \mathrm{rpm}$ at $4^{\circ} \mathrm{C}$ for $2 \mathrm{hr}$. The pellet was resuspended in $200 \mu \mathrm{l}$ of PBS, $400 \mu \mathrm{l}$ of RNX reagent was added, mixed well and incubated at room temperature for $5 \mathrm{~min}$. RNA was extracted with $0.2 \mathrm{ml}$ chloroform/ isoamylalcohol (24:1). The RNA, in the aqueous solution, was precipitated by adding an equal volume of isopropanol. The mixture was then centrifuged at $10,000 \times \mathrm{g}$ for $20 \mathrm{~min}$. The pellet was washed with $75 \%$ ethanol and dissolved in $20 \mu$ of DEPC water.

$R T-P C R$ and sequencing of sialidase. Reverse transcription followed by PCR was performed using specific primers $F$ ( $5^{\prime}$-aag tct tgc agt gtg agt gc-3') and $\mathrm{R}$ ( $5^{\prime}$-tca tct ttg agg atc tca ac-3') for amplification of $1000 \mathrm{bp}$ fragments of the sialidase sequence. RT-PCR was

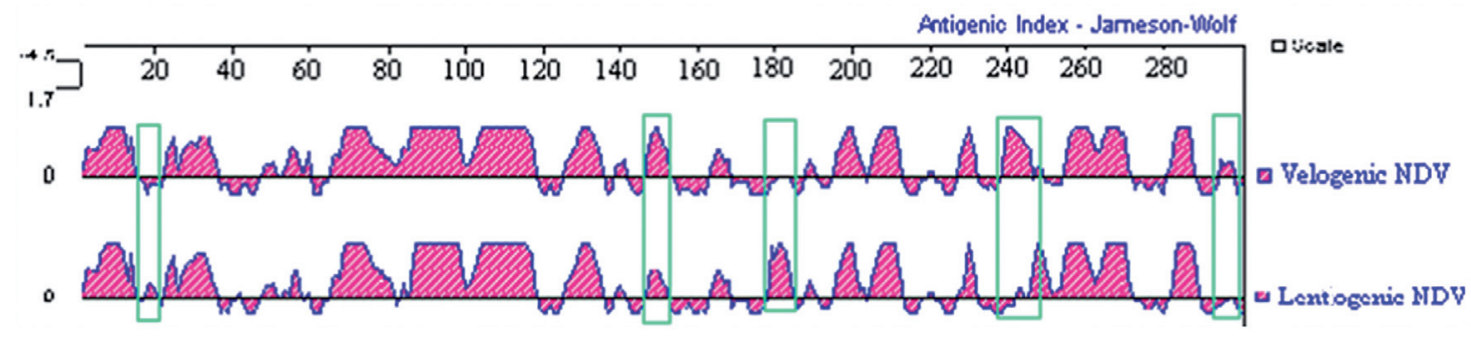

Fig. 2

Antigenic index of the sialidase protein of lentogenic and velogenic NDV strains
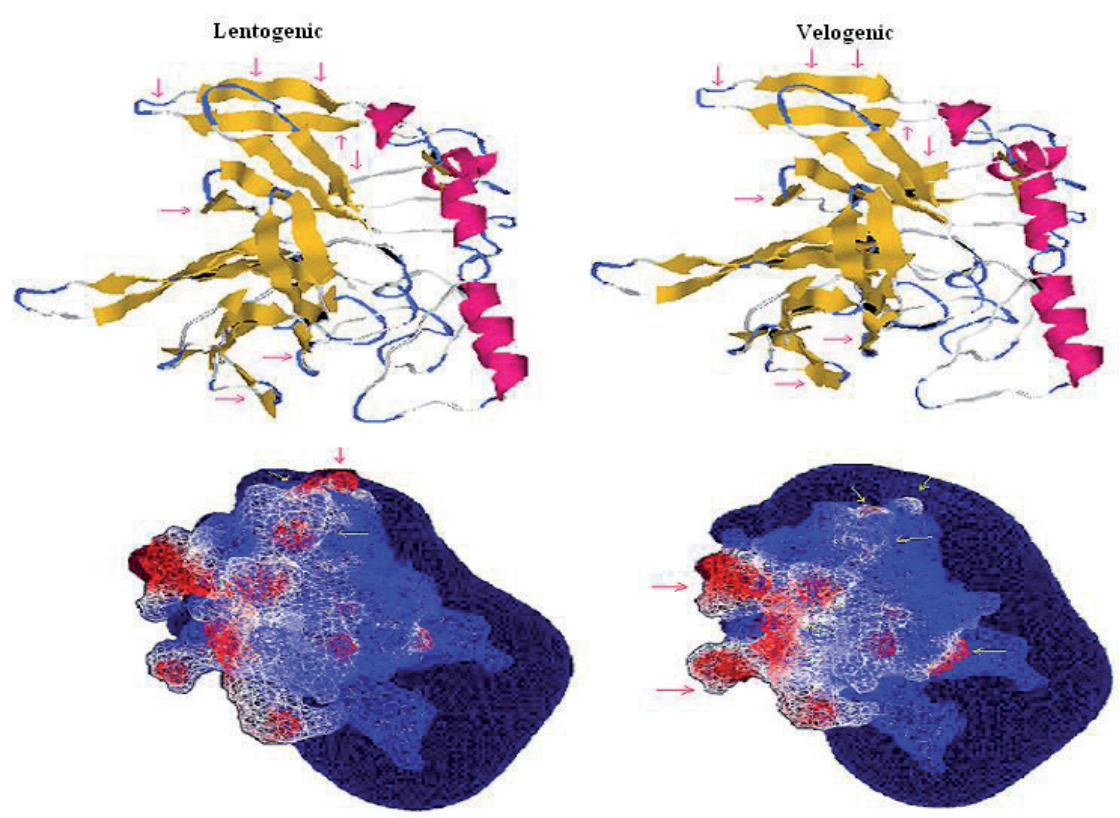

Fig. 3

Tertiary structure of the sialidase protein of velogenic and lentogenic NDV strains

Tertiary structure was predicted by I-TASSER with high score of 1.92. Electrostatic potential of the surface of the sialidase protein was computed by spdbv DeepViewer software in polymorphic residues of the sialidase protein of velogenic and lentogenic strains. 
performed in $50 \mu \mathrm{l}$ reaction mixture containing $10 \mu \mathrm{l}$ of $5 \times$ reaction buffer, $2.5 \mathrm{mmol} / \mathrm{l}$ each dNTPs, $1 \mu \mathrm{l}$ of AMV enzyme (Titan one tube RT-PCR system kit, Roche Diagnostic, Germany), 10 pmol/l each primer, $1 \mu \mathrm{g}$ total RNA, $2.5 \mu \mathrm{l}$ DTT $(0.1 \mathrm{M}), 1.5 \mathrm{mmol} / \mathrm{l} \mathrm{MgCl}_{2}$, and $23.5 \mu \mathrm{l}$ of $\mathrm{H}_{2} \mathrm{O}$. PCR program was $42^{\circ} \mathrm{C}$ for $1 \mathrm{hr}, 94^{\circ} \mathrm{C}$ for $3 \mathrm{~min}, 30$ cycles of $93^{\circ} \mathrm{C}$ for $30 \mathrm{sec}, 52^{\circ} \mathrm{C}$ for $30 \mathrm{sec}, 72^{\circ} \mathrm{C}$ for $1 \mathrm{~min}$, followed by $72^{\circ} \mathrm{C}$ for $5 \mathrm{~min}$. The PCR products were purified using PCR product purification kit (Roche). Sixteen PCR products ( 16 of 27 isolates) were purified from the $1 \%$ agarose gel and sequenced in both directions with forward and reverse primers (MWG Co.). These sequences were analyzed by MegAlign software from DNAstar Package.

Secondary and tertiary structure prediction. Secondary structure of sialidase protein and other biochemical parameters such as antigenic index, hydrophobicity and isoelectric point were compared in velogenic and lentogenic strains of NDVs by DNAstar and DNAsis software. Three-dimensional structure of sialidase protein was predicted using the homology-based method and this structure was viewed by spdbv DeepViewer (Fig. 3). Electrostatic potential was computed and compared between velogenic and lentogenic NDVs.

\section{Results}

Based on multiple alignment we identified seventeen amino acid residues in sialidase protein, $\mathrm{Asn}_{263} \rightarrow \mathrm{Lys}, \mathrm{Ala}_{265} \rightarrow \mathrm{Val}$,
Ile/Val ${ }_{266} \rightarrow$ Thr, $V_{288} \rightarrow$ Thr, $\mathrm{Thr}_{290} \rightarrow$ Val, Glu/Gly ${ }_{293} \rightarrow$ Lys, Asn/Ser ${ }_{310} \rightarrow$ Asp, Asp $_{342} \rightarrow$ Asn/Thr, Val ${ }_{390} \rightarrow$ Ile, Val ${ }_{395} \rightarrow$ Ile, $\mathrm{Ser}_{432} \rightarrow \mathrm{Tyr}, \mathrm{Val}_{466} \rightarrow \mathrm{Ile}, \mathrm{Tyr}_{479} \rightarrow \mathrm{H}, \mathrm{Ile}_{514} \rightarrow \mathrm{Val}, \mathrm{Lys}_{523} \rightarrow$ Arg, $\mathrm{Thr}_{540} \rightarrow$ Ala and $\mathrm{Asn}_{550} \rightarrow$ Asp, that differed between known lentogenic strains and velogenic NDVs (Iranian velogenic isolates), respectively (Fig. 1).

Ten specific amino acids (Arg in residue 269, Ser in residue 315 , Val in residue 329 , Ile in residue 369 , Ile in residue 404 , Ile in residue 453, Ile in residue 477, Gly in residue 494, Ala in residue 502 and Thr in residue 509) were identified in lentogenic strains (Lasota, B1 and other Lentogenic field isolate) but in velogenic NDV these amino acids were: Ser, Pro, Ala, Val, Val, Tyr, Val, Asp, Val and Ile (Fig. 1).

In lentogenic NDVs, one amidation pattern X-G[RK][RK] at the position 365-368, four myristoylation sites G- $\{$ EDRKHPFYW $\}=X(2)-[S T A G C N\}-\{P\}$, nine CK2-glycosylation sites [ST]-(2)-[DE] and one TYR-phosphorylation $[\mathrm{RK}]-\mathrm{X}(2,3)-[\mathrm{DE}]-\mathrm{X}(2,3)$ were identified. No differences in numbers and positions of amidation, myristoylation and CK2-phosphorylation sites between velogenic and lentogenic NDVs were observed. But, eight and five PKCphosphorylation sites were observed in sialidase protein of lentogenic and velogenic NDV strains, respectively. Lentogenic NDVs have three more phosphorylation sites than velogenic isolates at positions 432-434, 509-511, and

Table 2. Posttranslational modification sites in sialidase protein of lentogenic and velogenic NDVs

\begin{tabular}{|c|c|c|c|c|c|c|}
\hline \multicolumn{3}{|c|}{ Velogenic NDV } & \multicolumn{3}{|c|}{ Lentogenic NDV } & \multirow{2}{*}{$\begin{array}{c}\text { Posttranslation } \\
\text { modification sites }\end{array}$} \\
\hline Pattern & Position & No. & Pattern & Position & No. & \\
\hline $\mathrm{X}-\mathrm{G}[\mathrm{RK}]-[\mathrm{RK}]$ & $365-368$ & 1 & $\mathrm{X}-\mathrm{G}[\mathrm{RK}]-[\mathrm{RK}]$ & $365-368$ & 1 & AMIDATION \\
\hline \multirow[t]{4}{*}{$\mathrm{N}-\{\mathrm{P}\}-[\mathrm{ST}]-\{\mathrm{F}\}$} & $341-344$ & 3 & $\mathrm{~N}-\{\mathrm{P}\}-[\mathrm{ST}]-\{\mathrm{P}\}$ & $341-344$ & 4 & ${ }^{*}$ ASN_GLYCOSYL \\
\hline & $433-436$ & & & $433-436$ & & \\
\hline & $481-484$ & & & $481-484$ & & \\
\hline & & & & $538-541$ & & \\
\hline \multirow[t]{9}{*}[\mathrm{ST}]{$-(2)-[\mathrm{DE}]$} & $255-258$ & 9 & {$[\mathrm{ST}]-(2)-[\mathrm{DE}]$} & $255-258$ & 9 & CK2_PHOSPHO \\
\hline & $257-260$ & & & $257-260$ & & \\
\hline & 306-309 & & & 306-309 & & \\
\hline & $324-327$ & & & $324-327$ & & \\
\hline & $328-331$ & & & $328-331$ & & \\
\hline & $343-346$ & & & $343-346$ & & \\
\hline & $381-384$ & & & $381-384$ & & \\
\hline & $490-493$ & & & $490-493$ & & \\
\hline & $545-547$ & & & $545-547$ & & \\
\hline \multirow{4}{*}{$\begin{array}{c}\text { G- }\{\text { EDRKHP } \\
\text { FYW }\}=X(2)-[S T A G C N\}-\{P\}\end{array}$} & $301-306$ & 4 & G-\{EDRKHP & $301-306$ & 4 & MYRISTYL \\
\hline & 319-324 & & $\mathrm{FYW}\}=\mathrm{X}(2)-[\mathrm{STAGCN}\}-\{\mathrm{P}\}$ & $319-324$ & & \\
\hline & $451-456$ & & & $451-456$ & & \\
\hline & $486-491$ & & & $486-491$ & & \\
\hline \multirow[t]{8}{*}{ [ST]-X-[RK] } & $358-360$ & 5 & [ST]-X-[RK] & $358-360$ & 8 & ${ }^{\star}$ PKC_PHOSPHO \\
\hline & $375-377$ & & & $375-377$ & & \\
\hline & $458-460$ & & & $432-434$ & & \\
\hline & 483-485 & & & $458-460$ & & \\
\hline & $537-539$ & & & 483-485 & & \\
\hline & & & & $509-511$ & & \\
\hline & & & & $521-523$ & & \\
\hline & & & & $537-539$ & & \\
\hline$[\mathrm{RK}]-\mathrm{X}(2,3)-[\mathrm{DE}]-\mathrm{X}(2,3)$ & $274-281$ & 1 & {$[\mathrm{RK}]-\mathrm{X}(2,3)-[\mathrm{DE}]-\mathrm{X}(2,3)$} & $274-281$ & 1 & TYR_PHOSPHO \\
\hline
\end{tabular}


521-523. On the other hand, lentogenic NDVs have one glycosylation site more than velogenic isolates in sialidase protein, at the position $538-541$.

\section{Discussion}

Our results showed different pattern in amino acid sequences of sialidase protein between iranian velogenic isolates and known lentogenic NDV strains (B1, Lasota and V4). Iranian isolates showed low similarity $(\sim 82 \%)$ with all vaccine strains and high similarity ( 92-95\%) with other velogenic strains in GenBank. The HN protein of NDV is an important multifunctional envelope protein, which plays key roles in virus attachment, neuraminidase and fusion promotion activities. The HN gene of NDV has six glycosylation sites, two of which are not used for addition of carbohydrates. The exact role of the four functional glycosylation sites in NDV pathogenesis is unknown. Amino acid sequence alignment showed 17 amino acid variations in sialidase protein in residues $\mathrm{Asn}_{263} \rightarrow \mathrm{Lys}, \mathrm{Ala}_{265} \rightarrow \mathrm{Val}$, Ile/ $\mathrm{Val}_{266} \rightarrow \mathrm{Thr}, \mathrm{Val}_{288} \rightarrow \mathrm{Thr}, \mathrm{Thr}_{290} \rightarrow \mathrm{Val}, \mathrm{Glu} / \mathrm{Gly}_{293} \rightarrow \mathrm{Lys}, \mathrm{Asn} /$ $\mathrm{Ser}_{310} \rightarrow \mathrm{Asp}, \mathrm{D}_{342} \rightarrow \mathrm{N} / \mathrm{T}, \mathrm{Val}_{390} \rightarrow \mathrm{Ile}, \mathrm{Val}_{395} \rightarrow \mathrm{Ile}, \mathrm{Ser}_{432} \rightarrow \mathrm{Tyr}$, $\mathrm{Val}_{466} \rightarrow \mathrm{Ile}, \mathrm{Tyr}_{479} \rightarrow \mathrm{H}, \mathrm{Ile}_{514} \rightarrow \mathrm{Val} \mathrm{Lys}_{523} \rightarrow \mathrm{Arg}, \mathrm{Thr}_{540} \rightarrow \mathrm{Ala}$ and $\mathrm{Asn}_{550} \rightarrow$ Asp in lentogenic and velogenic NDVs, respectively. Three of sixteen amino acid variations in residues 432, 479, 549 were located near the three glycosylation sites of the sialidase protein. On the other hand, sialidase protein has seven active catalytic sites at the residues 174, 198, 401, $416,498,526$ and 547. Interestingly, the three amino acid residues 395, 523 and 550 were located in catalytic sites of sialidase protein.

We have also found differences in the number of PKCphosphorylation and Asn-glycosylation sites in two groups of NDVs. Lentogenic NDVs have three more phosphorylation sites than velogenic isolates, at positions 432-434, 509-511, and 521-523. Lentogenic also NDVs have one more glycosylation site than velogenic isolates in sialidase protein at the position 538-541.

The seventeen differing amino acids, especially six residues $395,432,479,523,540$ and 550, might have an effect in the pathogenesis of NDV. Previous studies showed that the HN protein along with the $\mathrm{F}$ protein is the main target of immune response against NDV (Meulemans et al., 1986, Morgan et al., 1992). A recent report (Zeng et al., 2002) indicated that the HN protein of NDV was responsible for induction of interferon-alpha and tumor necrosis factor. Since HN possesses immunogenic properties, studies on this protein may prove to be useful for the development of NDV vaccines.

The bioinformatic analysis of velogenic and lentogenic strains showed differences in the secondary structure of the sialidase protein and other biochemical properties such as hydrophobicity and isoelectric point. Also, these two groups of NDVs showed different pattern in posttranslational modification sites and electrostatic potential in the tertiary structure of the sialidase protein. These results indicated that the sialidase protein may have an effective role in the pathogenesis due to differences in amino acid sequences between velogenic and lentogenic strains. These results might be useful in designing molecular techniques for differentiation of velogenic and lentogenic isolates based on the differences in the sialidase protein.

Acknowledgements. This work was supported by grant No. 780411217000-04 from Razi Vaccine and Serum Research Institute. The authors thank Dr. Momayez and Dr. Pourbakhsh in Poultry Disease Research unit of Razi Vaccine and Serum Research Institute for preparation of virus samples.

\section{References}

Alexander DJ (1997): Newcastle disease and other avian Paramyxoviridae infection. In Calnek BW (Ed.): Disease of Poultry. 10th ed. Ames, Iowa State University Press, pp. 541-569.

Krishnamurthy S, Samal SK (1998): Nucleotide sequences of the trailer, nucleocapsid protein gene and intergenic regions of Newcastle disease virus strain Beaudette $C$ and completion of the entire genome sequence. J. Gen. Virol. 79, 2419-2424.

Lamb RA, Kolakofsky D (1996): Paramyxoviridae: In Fields BN, Knipe DM, Howley PM (Ed.): The Viruses and their Replication. Philadelphia: Lippincott-Raven, pp. 1177-1203.

McGinnes LW, Morrison T (1995): The role of individual oligosaccharides chains in the activities of the HN glycoprotein of the Newcastle disease virus. Virology 212, 398-410. http://dx.doi.org/10.1006/viro.1995.1497

Meulemans G, Gonze M, Carlier MC, Petit A, Burny A, Long L (1986): Protective efforts of HN and F protein glycoprotein-specific monoclonal antibodies on experimental Newcastle disease. Avian Pathol. 15, 761-768. http:// dx.doi.org/10.1080/03079458608436338

Morgan RW, Gelb J, Schreurs LS, Lutticken D, Rossenberger JK, Sondermeijer PJ (1992): Protection of chickens from Newcastle and Marek's diseases with a recombinant herpes virus of turkeys' vaccine expressing the Newcasthe disease virus fusion protein. Avian Dis. 36, 858-870. http://dx.doi.org/10.2307/1591544

Zeng J, Fournier P, Schirrmacher (2002): Induction of interferonalpha and tumor necrosis factor-related apoptosisinducing ligand in human blood mononuclear cells by hemagglutinin-neuraminidase but not $\mathrm{F}$ protein of Newcastle disease virus. Virology 297, 19-30. http:// dx.doi.org/10.1006/viro.2002.1413 